\title{
ADAPTIVE CHANGES IN THE ORNITHINE CYCLE AND AMINO ACID SYNTHESIS IN SHEEP LIVER WITH DIFFERENT MEAT PRODUCTIVITY
}

\author{
Tetiana Prylipko \\ State Agrarian and Engineering University in Podilya, Ukraine \\ E-mail: tprilipko59@gmail.com
}

Tetiana Koval State Agrarian and Engineering University in Podilya, Ukraine E-mail: koval_tanya@i.ua

Volodymyr Kostash State Agrarian and Engineering University in Podilya, Ukraine E-mail:kostashv@ukr.net

Volodymyr Tkachuk Zhytomyr National Agroecological University, Ukraine E-mail:vtl280726p@ukr.net

Alona Shuliar IJMT\& Zhytomyr National Agroecological University, Ukraine E-mail: alyonashulyar7@gmail.com

Submission: $8 / 5 / 2021$

Revision: 9/13/2021 Accept: 9/26/2021

ABSTRACT

The aim of the research was to study the ornithine cycle as the process of fixing ammonia and the formation of urea in the body of highly productive animals. In our experiments, we used a protein-deficient diet and urea as a nitrogen substitute for nitrogen-containing materials in the diet to reveal the mechanism of action of urea on animals, in particular on the biochemical processes of the ornithine cycle. There are some differences between Bukovinian sheep of the Askanian meat-wool breed and outbreds in terms of the ability to build muscle tissue. Our study reveals that the slaughter yield and the average daily gain consumtion of Bukovinian-type meat of the Askanian meat-wool breed was higher in summer and in autumn, compare with purebred sheep. Sheep of the Bukovynian type of Askanian meat- 
wool breed have the intensity of enzymatic formation of urea in liver homogenates that is much higher in all experiments than in outbred sheep.A sharp drop in the activity of all stages of urea formation and glutamic acid synthesis in liver homogenates and significantly weakened urea formation was found in all experiments of the fourth series in comparison with the experiments in the third series. Increased muscle growth, high nitrogen deposition, and a much lower percentage of urinary excretion of ammonia and urea nitrogen, as well as higher activity of enzymes of the ornithine cycle and glutamic acid synthesis in the Bukovinian sheep type of Askanian meat-wool breed compared to outbreeds allow concluding that ammonia and urea in highly productive animals act less as finishing products of nitrogen metabolism than in lowproductive animals.

Keywords: ornithine cycle; slaughter yield; synthesis; rock; substrate; urea; fermentation

\section{INTRODUCTION}

Under certain feeding conditions, the metabolism and productivity of animals change (Vdovichenko, Iovenko and Zharuk, 2016).

Of great theoretical interest is the study in animals of highly specialized synthesis of muscle proteins, milk and wool. For example, high-yielding bulls at the age of 2-3 years after feeding or fattening can weigh 400-500 kg and more, the yield of meat and fat in them is 260$325 \mathrm{~kg}$. A highly productive cow synthesizes about $150 \mathrm{~kg}$ of milk protein per year. Ascanian rambouillet sheep can produce about $25 \mathrm{~kg}$ of wool (protein keratin) per year (Chernomyz, Lesyk and Pokhivka, 2014; Prylipko, Koval and Kostash, 2021).

\section{LITERATURE REVIEW}

Sheep of precocious meat-wool breed, for example Bukovynian type of Askanian meatwool breed of sheep with crossbred wool, have the ability to fatten well, have a high slaughter weight; The average live weight of ewes is $56.8 \mathrm{~kg}$ (maximum $80.0 \mathrm{~kg}$ ), fertility $117 \%$ (maximum 152\%), wool length $12.8 \mathrm{~cm}$ (maximum - $19 \mathrm{~cm}$ ), shearing of pure wool $2.9 \mathrm{~kg}$ (maximum 5, $0 \mathrm{~kg}$ ). Lambs are characterized by high meat productivity, their pre-slaughter live weight at 9 months of age is $41.1 \mathrm{~kg}$, carcass weight is $20 \mathrm{~kg}$, slaughter yield is $51 \%$. two lambs. Lambs are born strong and large, the live weight of single lambs at birth is 4.0-6.0 kg, twin 3.8$5.0 \mathrm{~kg}$, triple $3.5-4.5 \mathrm{~kg}$. Under favorable feeding conditions, lambs up to 6 months of age reach a live weight of 36-42 kg. (Polska, 2001; Chernomyz, Lesyk and Pokhivka, 2014). 
Such intensive meat production in highly productive animals is due to the specialization of intermediate metabolic processes, due to which some of its substances are better used for meat protein synthesis than in low-yielding animals.

Animals of meat breeds have a special direction of metabolism towards better use of nitrogenous substances, intensive synthesis of amino acids and muscle proteins. Selection of animals for meat productivity is essentially at the same time selection for the peculiarity of nitrogen metabolism, as evidenced by the relatively large increase in muscle mass in such animals compared to non-meat, even with a relatively close content of amino acids in feed.

Meanwhile, these extremely interesting processes of nitrogen metabolism remain unexplored. In highly productive meat animals, increased synthetic liver function and a more active than usual process of muscle protein fixation of plasma proteins and free amino acids of the blood are expected. In such animals, the so-called end products of nitrogen metabolism ammonia and urea should be better utilized and increasingly take the value of intermediate products of metabolism (Scales, Bray and Baird, 2000).

Urea cannot be considered only as an irreversible end product of nitrogen metabolism (Nischemenko, Samoray and Prokopishina, 2012). In this regard, the study of the ornithine cycle - the process of fixation of ammonia and urea in the body of highly productive animals was the subject of our study. The main role in the synthetic formation of urea in mammals belongs to the liver. Krebs and Gensenleit's theory of urea formation involves the sequential conversion of ornithine to citrulline, citrulline to arginine, and the latter to urea and ornithine.

Further studies have shown that nitrogen donors in the biosynthesis of urea in the Krebs ornithine cycle are ammonia - in the first phase (ornithine $\rightarrow$ citrulline), as well as various Dand L-amino acids and ammonia - in the second phase (citrulline $\rightarrow$ arginine) (Zonabend, Ojango and Audho, 2017). A special role in the second phase belongs to aspartic acid - the direct source of half of urea nitrogen (Pașca, Cîmpean and Pusta, 2018).

One of the important processes of ammonia fixation in animals is the biosynthesis of amino acids from the corresponding keto acids.

The work of many authors is devoted to the study of the mechanisms of synthesis of the most important amino acids (alanine, glutamic, asparagine) (Pokhyl and Mykolaychuk, 2019). They were mainly performed on laboratory animals (rats) that were on a diet with normal and low protein content. 
It is of interest to study the synthesis of glutamic acid in different breeds with different levels of meat productivity and different protein content in the diet.

Glutamic acid plays an important role in the processes of nitrogen metabolism. It is more readily available for deamination, reamination, and synthesis than other amino acids. in most organisms, glutamic acid is synthesized earlier and more actively than other amino acids (Prylipko, Kostash and Koval 2021). In mammals, the independent value of direct reductive amination and deamination is reduced mainly to the formation and oxidation of glutamic acid.

This article discusses the synthesis of glutamic acid in the liver of high-yielding Bukovinian type of Askanian meat-wool breed of sheep, and in sheep with low meat productivity.

To study the genetic specificity of different breeds in the synthesis of meat proteins and test lability of this process, for experimental animals were rations different in protein content. In our experiments, we used a protein-deficient diet and urea as a nitrogen substitute for nitrogen-containing substances in the diet (Pokhyl and Mykolaychuk, 2019).

The disclosure of the mechanism of action of urea on the body of animals, in particular on the biochemical processes of the ornithine cycle, is of great theoretical interest.

\section{DATA AND METHODOLOGY}

24 lambs were used: 12 Bukovinian type of Askanian meat-wool breed of sheep and 12 cows of coarse-haired local sheep, which in the text we will conditionally call outbred. 4 series of experiments were performed, in each of which there were analogous animals under the experiment: 3 lambs of Bukovynian type of Askanian meat-wool breed and 3 lambs of outbred ones. The conditions for keeping the animals were the same.

The first series. Animals 4-5 months of age received a diet for growing breeding lambs (in terms of total nutrition and crude protein content). The experiments lasted from May 28 to July 17.

The second series. Animals 4-5 months of age received the same diet as in the first series, but $18.6 \%$ of the protein in the diet was replaced by urea (the coefficient of conversion of the missing protein to urea - 2.6). The duration of the experiments is from May 28 to July 17.

The third series. Animals 8-9 months of age were fed a diet of growing breeding lambs. The experiments lasted from September 8 to October 28 . 
INDEPENDENT JOURNAL OF MANAGEMENT \& PRODUCTION (IJM\&P)

http://www.ijmp.jor.br

v. 12, n. 6, Special Edition ISE, S\&P - November 2021

ISSN: 2236-269X

DOI: 10.14807/ijmp.v12i6.1751

The fourth series. The diet for animals 8-10 months of age contained 2.8 times less protein than in the diet for sheep of the third series. The experiments were conducted from September 8 to December 4.

The lack of total nutritional value of the diets in the second and fourth series of experiments was filled with an equivalent amount of digestible starch. Sheep were gradually accustomed to eating urea.

Each decade the animals were weighed and the increments were taken into account, and the slaughter yield of meat was determined at the end of the experiment (Table 1).

Table 1: Growth of experimental sheep and slaughter yield of meat

\begin{tabular}{|c|c|c|c|c|c|c|c|c|c|c|}
\hline \multirow{2}{*}{$\begin{array}{c}\text { Duration of } \\
\text { experiments } \\
\text { (days) }\end{array}$} & \multirow{2}{*}{$\begin{array}{l}\text { A series of } \\
\text { experiments }\end{array}$} & \multirow[t]{2}{*}{$\begin{array}{c}\text { Experiment } \\
\text { number }\end{array}$} & \multicolumn{4}{|c|}{$\begin{array}{l}\text { Bukovinian type of Askanian meat- } \\
\text { wool breed of sheep }\end{array}$} & \multicolumn{4}{|c|}{ Outbred sheep } \\
\hline & & & \begin{tabular}{|c|} 
weight \\
when \\
setting up \\
for the \\
experiment \\
$(\mathrm{kg})$ \\
\end{tabular} & $\begin{array}{c}\text { weight } \\
\text { before } \\
\text { slaughter } \\
(\mathrm{kg})\end{array}$ & $\begin{array}{c}\text { average } \\
\text { daily } \\
\text { growth } \\
(\mathrm{g})\end{array}$ & $\begin{array}{c}\text { slaughter } \\
\text { yield of } \\
\text { meat } \\
(\%)\end{array}$ & \begin{tabular}{|c|} 
weight \\
when \\
setting up \\
for the \\
experiment \\
$(\mathrm{kg})$ \\
\end{tabular} & \begin{tabular}{|c} 
weight \\
before \\
slaughter \\
$(\mathrm{kg})$
\end{tabular} & $\begin{array}{c}\text { average } \\
\text { daily } \\
\text { growth } \\
(\mathrm{g})\end{array}$ & $\begin{array}{c}\text { slaughter } \\
\text { yield of } \\
\text { meat } \\
(\%)\end{array}$ \\
\hline 32 & \multirow{3}{*}{1} & 1 & 20 & 28,2 & 256 & 49,5 & 17 & 21,5 & 140 & 37,2 \\
\hline 40 & & 2 & 20 & 30,4 & 260 & 42,4 & 19 & 24,2 & 130 & 33,0 \\
\hline 50 & & 3 & 19 & 28,0 & 180 & 46,4 & 18 & 20,5 & 50 & 34,1 \\
\hline Medium & - & - & 19,7 & 28,9 & 232 & 46,1 & 18 & 22,1 & 107 & 34,8 \\
\hline 54 & \multirow{3}{*}{2} & 4 & 16 & 26,0 & 185 & 46,5 & 16 & 20,0 & 74 & 35,0 \\
\hline 55 & & 5 & 20 & 26,5 & 118 & 42,3 & 22 & 27,0 & 91 & 39,6 \\
\hline 59 & & 6 & 16 & 24,5 & 127 & 42,8 & 17 & 22,3 & 90 & 37,4 \\
\hline Medium & - & - & 17,3 & 25,7 & 143 & 43,9 & 18,3 & 23,1 & 85 & 37,3 \\
\hline 30 & \multirow{3}{*}{3} & 7 & 24 & 33,3 & 310 & 46,8 & 24 & 28,6 & 153 & 33,3 \\
\hline 42 & & 8 & 26,2 & 39,5 & 316,6 & 43,5 & 25 & 34,5 & 226 & 36,6 \\
\hline 50 & & 9 & 23 & 35,0 & 240 & 47,1 & 22 & 30,0 & 160 & 38,3 \\
\hline Medium & - & - & 24,4 & 35,9 & 288,9 & 45,8 & 23,7 & 31,0 & 179,7 & 36,1 \\
\hline 42 & \multirow{3}{*}{4} & 10 & 22 & 26,2 & 100 & 47,3 & 23 & 27,5 & 95 & 35,8 \\
\hline 76 & & 11 & 21 & 29,7 & 114 & 40,8 & 20,5 & 26,3 & 88 & 38,1 \\
\hline 86 & & 12 & 21 & 31,7 & 125 & 44,5 & 20 & 26,3 & 73,2 & 36,5 \\
\hline Medium & - & - & 21,3 & 29,2 & 113 & 44,2 & 21,2 & 26,7 & 85,4 & 37,5 \\
\hline
\end{tabular}

Source: created by the authors

Balance experiments on nitrogen metabolism were performed on 12 lambs (Table 2).

Animals were slaughtered after a 20-hour fast. The removed liver was placed for 20 minutes to cool in potassium phosphate buffer $(\mathrm{pH} 7.4)$ at a temperature of about $0^{\circ} \mathrm{C}$.

Staging experiments with homogenates. Liver tissue was homogenized with three times the volume of potassium phosphate buffer $(0.1 \mathrm{M} ; \mathrm{pH} 7.4)$ in a glass homogenizer for 2 minutes at 2.5 thousand revolutions. 
DOI: 10.14807/ijmp.v12i6.1751

Table 2: Average daily nitrogen balances in experimental sheep $(\mathrm{g})$

\begin{tabular}{|c|c|c|c|c|c|c|c|c|c|c|c|c|c|c|c|c|c|}
\hline \multirow{4}{*}{\multicolumn{2}{|c|}{ 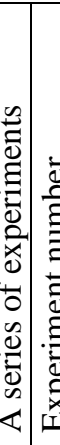 }} & \multicolumn{8}{|c|}{ Bukovinian type of Askanian meat-wool breed of sheep } & \multicolumn{8}{|c|}{ Outbred sheep } \\
\hline & & \multirow[b]{3}{*}{ 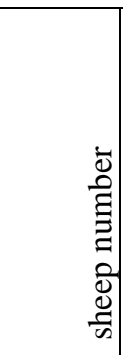 } & \multirow{3}{*}{ 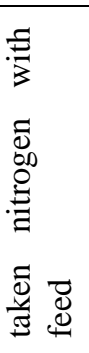 } & \multicolumn{4}{|c|}{ released nitrogen } & \multirow[b]{3}{*}{ 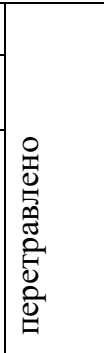 } & \multirow[b]{3}{*}{ 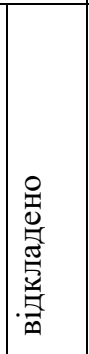 } & \multirow{3}{*}{\multicolumn{2}{|c|}{ 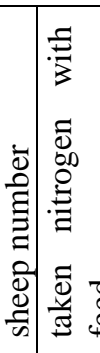 }} & \multirow{2}{*}{\multicolumn{4}{|c|}{$\begin{array}{c}\text { released nitrogen } \\
\text { with urine }\end{array}$}} & \multirow[b]{3}{*}{ 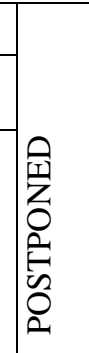 } & \multirow[b]{3}{*}{ 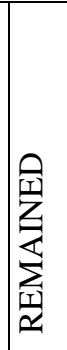 } \\
\hline & & & & & & vith ur & & & & & & & & & & & \\
\hline & & & & 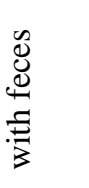 & 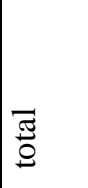 & 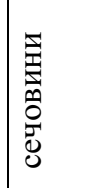 & . & & & & & 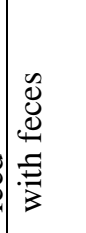 & 胥 & 巳্巳 & 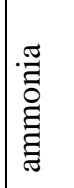 & & \\
\hline 1 & 1 & $1-361$ & 30,90 & 8,67 & 13,44 & 10,02 & 0,396 & 22,21 & 8,77 & 1 & 27,4 & 6,65 & 15,6 & 10,97 & 0,54 & $320,7^{7}$ & 75,17 \\
\hline 1 & 2 & $3-395$ & 31,82 & 8,87 & 14,72 & 10,44 & 0,47 & 22,94 & 7,23 & 3 & 27,6 & 6,99 & 16,1 & 13,81 & 0,66 & 20,6 & 84,5 \\
\hline 2 & 3 & $6-355$ & 30,39 & 7,36 & 16,48 & 10,41 & 1,46 & 23,03 & 5,55 & & 27,8 & 7,36 & 17,42 & 13,63 & 2,39 & 20,5 & 1,0 S \\
\hline 3 & 4 & $8-356$ & 35,90 & 11,74 & 14,90 & 11,74 & 0,7 & 24,16 & 9,26 & 8 & 33,5 & 13,37 & 7) 13,0 & 11,38 & 0,87 & 20,1 & 57,15 \\
\hline 4 & 5 & $11-362$ & 13,75 & 4,68 & 6,06 & 4,24 & 1,2 & 9,07 & 3,01 & 11 & 13,1 & 4,43 & 6,26 & 4,78 & 0,90 & 8,74 & 2,48 \\
\hline 4 & 6 & $12-415$ & 13,23 & 4,03 & 6,36 & 4,39 & 1,1 & 9,20 & 2,84 & & 12,5 & 4,19 & 6,8 & 5,36 & 1,32 & 8,36 & 1,5 \\
\hline
\end{tabular}

Source: created by the authors

During homogenization, EDTA (Na2-ethylenediaminetetraacetate) - $5 \mathrm{mg}$ per $1 \mathrm{ml}$ of homogenate was added to the buffer. In the experimental sample with a final volume of $4 \mathrm{ml}$ was made homogenate $0.5 \mathrm{ml}$, ATP $15 \mu \mathrm{m}, \mathrm{MgSO} 410 \mu \mathrm{m}, \mathrm{d}$-, 1-ornithine monohydrochloride $40 \mu \mathrm{m}$, citric acid $20 \mu \mathrm{m}$, glutamic acid $100 \mu \mathrm{m}, \mathrm{NH} 4 \mathrm{Cl} 20 \mu \mathrm{m}, \mathrm{NaHCO} 3$ - in the study of the first phase of the ornithine cycle and homogenate $0.5 \mathrm{ml}$, ATP $10 \mu \mathrm{m}, \mathrm{MgSO} 410 \mu \mathrm{m}, \mathrm{d}-, \mathrm{l}-$ citrulline $40 \mu \mathrm{m}$, citric acid $20 \mu \mathrm{m}$, aspartic acid $20 \mu \mathrm{m}$ - in the study of the second phase.

The samples were incubated at $38^{\circ} \mathrm{C}$ in an oxygen atmosphere with oscillation for one hour; was fixed with $1 \mathrm{~lm}$ of $20 \%$ trichloroacetic acid and centrifuged. $0.5 \mathrm{ml}$ of homogenate, $10 \mathrm{ml}$ of 1-arginine and potassium-phosphate buffer with a $\mathrm{pH}$ of 9.2 were added to the sample with a final volume of $4 \mathrm{ml}$. The reaction was stopped by adding $1 \mathrm{ml}$ of $20 \%$ trichloroacetic acid to the sample. In protein-free centrifuges of incubated samples, urea in Conway cups was determined using urease.

The activity of enzymes was expressed in micromoles of urea formed per $1 \mathrm{~g}$ of fresh tissue per hour.

In the study of glutamic acid biosynthesis, the liver was kept in an ice-cold $1.15 \% \mathrm{KCl}$ solution; other operations are the same as in the experiments in the study of the first and second phases of the ornithine cycle, but the $\mathrm{pH}$ of potassium phosphate buffer was $7.2 .2 \cdot 10-3 \mathrm{M}$ ATP, $2 \cdot 10-3 \mathrm{M} \mathrm{MgSO} 4,3 \cdot 10-2 \mathrm{M}$ (NH4) $2 \mathrm{CO} 3$ and 80 micromoles of $\alpha$-ketoglutaric acid. 
DOI: 10.14807/ijmp.v12i6.1751

. The reaction was stopped by adding $1 \mathrm{ml}$ of $20 \%$ trichloroacetic acid to the sample, the samples were centrifuged at 4-5 thousand revolutions for 5 minutes.

Total amino nitrogen was determined using ninhydrin by the method of Moore, Spahman and Stein (Ibatullin, Zhukorsky and Bashchenko, 2017).

The principle of the method (Kotsiumbas, Shcherbakovska \& Kotsiumbas, 2012) is as follows: the amount of amino nitrogen is determined by colorimetric method by the intensity of the color of the complex, which is formed by the interaction of amino groups with ninhydrin reagent. Reagents used to determine total amino nitrogen: $0.04 \mathrm{n}$ acetic acid solution, $1 \%$ hydrogen ninhydrin solution. The analysis consists of several stages: 1 . Deposition of proteins. $0.5 \mathrm{ml}$ of serum and $0.5 \mathrm{ml}$ of acetic acid solution are added to the centrifuge tubes, the tubes are closed with stoppers and placed in a cold water bath. The water in the bath is brought to a boil. The samples are boiled for 5 minutes. The tubes are then cooled. 2. Filtering. Add $1 \mathrm{ml}$ of distilled water to the contents of the tubes, mix and filter the solution into a $10 \mathrm{ml}$ volumetric tube. The centrifuge tube and filter are washed 2 more times, each time taking $1 \mathrm{ml}$ of distilled water.

Reaction with ninhydrin. To the filtrate add $0.5 \mathrm{ml}$ of ninhydrin solution. The contents of the tubes are mixed and incubated in a boiling bath for 20 minutes.

Then the tubes are cooled in water for $5 \mathrm{~min}$ at room temperature, then the solution in the tubes is adjusted with distilled water to $10 \mathrm{ml}$. Control and standard samples are placed in parallel. Control sample: to $3 \mathrm{ml}$ of distilled water add $0.5 \mathrm{ml}$ of acetic acid solution, $0.5 \mathrm{ml}$ of ninhydrin solution, after stirring boil for 20 minutes. Next, the control samples are processed as experimental. 4. Colorimetry. The density of the samples is measured on the FEC with a green light filter $(\lambda=540 \mathrm{~nm})$ in a $5 \mathrm{~mm}$ cuvette. The results are compared with similar data of the control sample and water

The control was samples incubated with all additives except $\alpha$-ketoglutaric acid. The test results were expressed in micromoles of amino nitrogen formed per $1 \mathrm{~g}$ of fresh tissue per hour.

\section{RESULTS AND DISCUSSIONS}

Urea biosynthesis in liver homogenates of experimental sheep in the first phase of urea formation is shown in table 3 . 
INDEPENDENT JOURNAL OF MANAGEMENT \& PRODUCTION (IJM\&P)

http://www.ijmp.jor.br

v. 12, n. 6, Special Edition ISE, S\&P - November 2021

ISSN: 2236-269X

DOI: 10.14807/ijmp.v12i6.1751

Table 3: Biosynthesis of urea when making ornithine in liver homogenates (in micromoles per $1 \mathrm{~g}$ of tissue per hour, $\mathrm{pH} 7.4$ )

\begin{tabular}{|c|c|c|c|c|}
\hline \multirow{2}{*}{$\begin{array}{l}\text { A series of } \\
\text { experiments }\end{array}$} & \multirow{2}{*}{$\begin{array}{c}\text { Duration of } \\
\text { experiments (days) }\end{array}$} & \multicolumn{2}{|l|}{ Urea increase } & \multirow[b]{2}{*}{$\mathrm{P}$} \\
\hline & & $\begin{array}{c}\text { Bukovinian type of Askanian } \\
\text { meat-wool breed of sheep }\end{array}$ & Outbred sheep & \\
\hline \multirow{3}{*}{1} & 32 & 27,0 & 5,7 & \\
\hline & 40 & 20,0 & 3,1 & \\
\hline & 50 & 20,0 & 8,5 & \\
\hline $\mathrm{M} \pm \mathrm{m}$ & - & $22,3 \pm 2,4$ & $5,8 \pm 1,5$ & $\overrightarrow{0,01}$ \\
\hline \multirow{3}{*}{2} & 54 & 20,0 & 5,7 & \\
\hline & 55 & 25,7 & 8,5 & \\
\hline & 59 & 28,0 & 17,0 & \\
\hline $\mathrm{M} \pm \mathrm{m}$ & - & $24,6 \pm 2,4$ & $10,4 \pm 3,4$ & $>0,01$ \\
\hline \multirow{3}{*}{3} & 30 & 57,3 & 34,3 & \\
\hline & 42 & 62,8 & 34,8 & \\
\hline & 50 & 52,6 & 30,1 & \\
\hline $\mathrm{M} \pm \mathrm{m}$ & - & $57,6 \pm 3$ & $33,1 \pm 1,5$ & $>0,002$ \\
\hline \multirow{3}{*}{4} & 42 & 8,4 & 4,3 & \\
\hline & 76 & 10,0 & 5,7 & \\
\hline & 86 & 7,1 & 2,9 & \\
\hline $\mathrm{M} \pm \mathrm{m}$ & - & $8,5 \pm 0,8$ & $4,3 \pm 0,9$ & $>0,001$ \\
\hline
\end{tabular}

Source: created by the authors

The urea biosynthesis in the first phase of the ornithine cycle in the Bukovynian type of Askanian meat-wool breed of sheep was higher in all experiments compared to the biosynthesis in outbred sheep.

The difference in enzymatic activity in this group averaged: in the first series - $16.5 \mu \mathrm{m}$, or $284.4 \%$; in the second series $-14.2 \mu \mathrm{m}$, or $136.5 \%$; in the third series $-24.5 \mu \mathrm{m}$, or $74 \%$; and in the fourth series $-4.2 \mu \mathrm{m}$, or $97.3 \%$.

Table 4 shows the results of experiments on urea biosynthesis in the second phase of the ornithine cycle.

As can be seen, the activity of the enzymatic process in this phase was higher in the Bukovinian type of Askanian meat-wool breed of sheep compared to outbred sheep in the first series of experiments by $16.2 \mu \mathrm{M}$, or $101.9 \%$; in the second series - by $22.9 \mu \mathrm{m}$, or $241 \%$; in the third series - by $27.2 \mu \mathrm{m}$, or $61.9 \%$; in the fourth series - by $5.4 \mu \mathrm{m}$, or $80 \%$.

Arginase activity in liver homogenates of experimental animals is shown in table 5.

In this phase, as in the previous ones, the biosynthesis of urea in purebred sheep was higher than in outbred.

In the first series, the difference in arginase activity was $2283 \mu \mathrm{m}$, or $59.5 \%$; in the second series $-613 \mu \mathrm{m}$, or $34.6 \%$; in the third series $-4487 \mu \mathrm{m}$, or $103.8 \%$; in the fourth series - $1959 \mu \mathrm{m}$, or $72.2 \%$. 
INDEPENDENT JOURNAL OF MANAGEMENT \& PRODUCTION (IJM\&P)

http://www.ijmp.jor.br

v. 12, n. 6, Special Edition ISE, S\&P - November 2021

ISSN: 2236-269X

DOI: 10.14807/ijmp.v12i6.1751

Table 4: Urea biosynthesis when citrulline is added to liver homogenates (in micromoles per

$1 \mathrm{~g}$ of tissue per hour, $\mathrm{pH} 7.4$ )

\begin{tabular}{|c|c|c|c|c|}
\hline \multirow{2}{*}{$\begin{array}{l}\text { A series of } \\
\text { experiments }\end{array}$} & \multirow{2}{*}{$\begin{array}{c}\text { Duration of } \\
\text { experiments (days) }\end{array}$} & \multicolumn{2}{|c|}{ Urea increase } & \multirow[b]{2}{*}{$P$} \\
\hline & & $\begin{array}{l}\text { Bukovinian type of Askanian } \\
\text { meat-wool breed of sheep }\end{array}$ & Outbred sheep & \\
\hline \multirow{3}{*}{1} & 32 & 31,3 & 19,5 & \\
\hline & 40 & 39,3 & 17,0 & \\
\hline & 50 & 35,6 & 11,3 & \\
\hline $\mathrm{M} \pm \mathrm{m}$ & - & $32,1 \pm 3,9$ & $15,9 \pm 2,4$ & $<0,02$ \\
\hline \multirow{3}{*}{2} & 54 & 52,3 & 9,5 & \\
\hline & 55 & 33,6 & 7,7 & \\
\hline & 59 & 31,3 & 11,3 & \\
\hline $\mathrm{M} \pm \mathrm{m}$ & - & $32,4 \pm 1,2$ & $9,5 \pm 1,8$ & $>0,001$ \\
\hline \multirow{3}{*}{3} & 30 & 74,1 & 39,9 & \\
\hline & 42 & 71,0 & 42,8 & \\
\hline & 50 & 68,2 & 49,0 & \\
\hline $\mathrm{M} \pm \mathrm{m}$ & - & $71,1 \pm 1,7$ & $43,9 \pm 2,7$ & $>0,001$ \\
\hline \multirow{3}{*}{4} & 42 & 12,2 & 6,8 & \\
\hline & 76 & 12,9 & 6,5 & \\
\hline & 86 & 11,5 & 7,1 & \\
\hline $\mathrm{M} \pm \mathrm{m}$ & - & $12,2 \pm 0,4$ & $6,8 \pm 0,2$ & $>0,001$ \\
\hline
\end{tabular}

Source: created by the authors

Table 5. Arginase activity in liver homogenates of experimental sheep at $\mathrm{pH} 9.2$ (in micromoles per $1 \mathrm{~g}$ of tissue per hour)

\begin{tabular}{|c|c|c|c|c|}
\hline \multirow{2}{*}{$\begin{array}{l}\text { A series of } \\
\text { experiments }\end{array}$} & \multirow{2}{*}{$\begin{array}{l}\text { Duration of } \\
\text { experiments } \\
\quad \text { (days)) }\end{array}$} & \multicolumn{2}{|c|}{ Urea increase } & \multirow[b]{2}{*}{$P$} \\
\hline & & $\begin{array}{l}\text { Bukovinian type of } \\
\text { Askanian meat-wool } \\
\text { breed of sheep }\end{array}$ & Outbred sheep & \\
\hline \multirow{3}{*}{1} & 32 & 9037 & 5478 & \\
\hline & 40 & 4795 & 3149 & \\
\hline & 50 & 4518 & 2874 & \\
\hline $\mathrm{M} \pm \mathrm{m}$ & - & $6117 \pm 1392$ & $3834 \pm 827$ & $<0,02$ \\
\hline \multirow{3}{*}{2} & 54 & 2598 & 1914 & \\
\hline & 55 & 2089 & 1344 & \\
\hline & 59 & 2464 & 2054 & \\
\hline $\mathrm{M} \pm \mathrm{m}$ & - & $2384 \pm 153$ & $1771 \pm 217$ & $<0,02$ \\
\hline \multirow{3}{*}{3} & 30 & 6573 & 3846 & \\
\hline & 42 & 9862 & 3640 & \\
\hline & 50 & 9991 & 5479 & \\
\hline $\mathrm{M} \pm \mathrm{m}$ & - & $8809 \pm 1112$ & $4321 \pm 580$ & $<0,02$ \\
\hline \multirow{3}{*}{4} & 42 & 4800 & 3200 & \\
\hline & 76 & 5376 & 3153 & \\
\hline & 86 & 3834 & 1779 & \\
\hline $\mathrm{M} \pm \mathrm{m}$ & - & $4670 \pm 357$ & $2711 \pm 467$ & $>0,01$ \\
\hline
\end{tabular}

Table 6 shows the results of studies of glutamic acid biosynthesis in liver homogenates of experimental sheep.

More intensive biosynthesis was observed in meat and wool compared to outbred sheep in all experiments. The difference in the first series was $618 \mu \mathrm{m}$, or $130 \%$; in the second series - $213 \mu \mathrm{m}$, or $87 \%$; in the third series - $963 \mu \mathrm{m}$, or $135 \%$; in the fourth series, $66.4 \mu \mathrm{M}$, or $132.5 \%$. 
INDEPENDENT JOURNAL OF MANAGEMENT \& PRODUCTION (IJM\&P)

http://www.ijmp.jor.br

v. 12, n. 6, Special Edition ISE, S\&P - November 2021

ISSN: 2236-269X

DOI: 10.14807/ijmp.v12i6.1751

Table 6: Biosynthesis of glutamic acid from $\alpha$-ketoglutaric acid and ammonium carbonate in liver homogenates of experimental sheep (in micromoles per $1 \mathrm{~g}$ of tissue per hour)

\begin{tabular}{|c|c|c|c|c|}
\hline \multirow{2}{*}{$\begin{array}{l}\text { A series of } \\
\text { experiments }\end{array}$} & \multirow{2}{*}{$\begin{array}{c}\text { Duration of } \\
\text { experiments (days)) }\end{array}$} & \multicolumn{2}{|c|}{ ammonium } & \multirow[b]{2}{*}{$\mathrm{P}$} \\
\hline & & $\begin{array}{l}\text { Bukovinian type of } \\
\text { Askanian meat- } \\
\text { wool breed of } \\
\text { sheep }\end{array}$ & Outbred sheep & \\
\hline \multirow{3}{*}{1} & 32 & 1230 & 413 & \\
\hline & 40 & 857 & 540 & \\
\hline & 50 & 1198 & 472 & \\
\hline $\mathrm{M} \pm \mathrm{m}$ & - & $1093 \pm 37,7$ & $475 \pm 36,7$ & $>0,01$ \\
\hline \multirow{3}{*}{2} & 54 & 530 & 332 & \\
\hline & 55 & 450 & 205 & \\
\hline & 59 & 394 & 198 & \\
\hline $\mathrm{M} \pm \mathrm{m}$ & - & $458 \pm 39,3$ & $245 \pm 43,5$ & $>0,01$ \\
\hline \multirow{3}{*}{3} & 30 & 1795,5 & 661,2 & \\
\hline & 42 & 1890,5 & 530,6 & \\
\hline & 50 & 1338,0 & 945,4 & \\
\hline $\mathrm{M} \pm \mathrm{m}$ & - & $1675 \pm 171$ & $712 \pm 122$ & $<0,01$ \\
\hline \multirow{3}{*}{4} & 42 & 151,1 & 65,4 & \\
\hline & 76 & 120,0 & 41,7 & \\
\hline & 86 & 78,3 & 43,3 & \\
\hline $\mathrm{M} \pm \mathrm{m}$ & - & $116 \pm 21$ & $50 \pm 7,5$ & $>0,05$ \\
\hline
\end{tabular}

However, in all experiments, the same pattern was obtained - much higher activity of enzyme systems of urea formation and glutamic acid synthesis in the Bukovinian type of Askanian meat-wool breed of sheep in comparison with outbred sheep.

The experiments revealed some differences between Bukovinian sheep of the Askanian meat-wool breed and outbreds in terms of the ability to build muscle tissue. With a complete diet, the slaughter yield of Bukovinian meat of the Askanian meat-wool breed was 32.5\% higher in summer and $27 \%$ in autumn, and the average daily gain was $117 \%$ higher in summer and $60 \%$ higher in autumn than in outbred sheep.

Studies of the activity of the three phases of the ornithine cycle in such sheep with different meat productivity showed that in the Bukovinian type of Askanian meat-wool breed the intensity of enzymatic urea formation in liver homogenates was in all experiments much higher than in outbred sheep; in the first phase - by 74-284.4\%; in the second - by 61.9-241; in the third (arginase) - by 34.6-103.8\%, and the synthesis of glutamic acid - by $87-135 \%$.

The greatest activity of urea and glutamic acid biosynthesis was observed in the experiments of the first and third series, when the animals received rations with sufficient protein content. The activity in this case was higher in the third series of experiments compared to the first; in sheep of Bukovynian type of Askanian meat-wool breed in the first phase of the ornithine cycle - by $158.3 \%$, in the second phase - by $117.4 \%$, in the third phase - by $44 \%$ and 
DOI: 10.14807/ijmp.v12i6.1751

the synthesis of glutamic acid - by $53.2 \%$, in outbred sheep - by $470.7 \%, 176.1 \%, 12.7 \%$, $126.7 \%$, respectively. High activity of enzymes of nitrogen metabolism in the third series of experiments can be caused by age changes of animals and time of carrying out experiments (seasonality).

Urea, which is introduced with food, significantly affected the process of urea formation in the body (comparison of experiments of the first and second series). In homogenates, where the substrate was ornithine (the first phase of the ornithine cycle), it activated the process of urea formation in the Bukovinian type of Askanian meat-wool breed by $10.3 \%$, in outbred - by $62 \%$. In liver homogenates with the addition of citrulline (second phase) inhibition of urea formation was observed in outbred sheep by $67.3 \%$; in the Bukovinian type of Askanian meatwool breed such action is practically not revealed.

In the third phase, the addition of urea caused a decrease in the activity of the enzyme: in the Bukovinian type of Askanian meat-wool breed of sheep - by $3733 \mathrm{~mA}$, or $156.5 \%$, in outbred = by $2063 \mathrm{mM}$, or $116.5 \%$. The synthesis of glutamic acid in this case was reduced in sheep of the Bukovina type of Askanian meat-wool breed by $87 \%$, in outbred - by $51 \%$.

We observed a sharp drop in the activity of all stages of urea formation and glutamic acid synthesis in liver homogenates in all experiments of the fourth series in comparison with the experiments in the third series. In this case, as a result of low protein content in the diet of sheep significantly reduced urea formation: in sheep of the Bukovinian type of Askanian meatwool breed in the first phase in 6.8 times, in the second - 5.8 times, in the third - in 1,9 times; synthesis of glutamic acid - 14.3 times; in outbred sheep the activity of the ornithine cycle decreased by 7.7 and 6.5, respectively. 1.6 times and the synthesis of glutamic acid 14 times. In local sheep, there are more pronounced changes in the formation of the Bukovinian type of Askanian meat-wool breed.

The results of the study of nitrogen balances (in 12 animals) also confirm significant differences in nitrogen metabolism of sheep. At the normal content in the diet of crude protein (1st and 2nd experiments) in outbred sheep in the body deposited nitrogen on average $4.9 \mathrm{~g}$, sheep Bukovynian type Askanian meat and wool breed - 8 g, or $63.3 \%$ more. Accordingly, the average daily gain in the experiments of Bukovynian type of Askanian meat-wool breed was higher by $129.4 \%$, and the slaughter yield of meat was $34.5 \%$ higher than in outbred sheep.

In the third experiment in the body of sheep of the Bukovinian type of Askanian meatwool breed nitrogen was deposited by $80 \%$ more, which corresponds to a higher increase in it 
DOI: 10.14807/ijmp.v12i6.1751

(by $41 \%$ ) and a higher slaughter yield of meat (by 14.7\%) compared with a purebred sheep. In sheep that received complete crude protein in the first and second experiments, more nitrogen was deposited than in sheep in the third experiment, where part of the protein was replaced by urea: in sheep Bukovynian type Askanian meat and wool breed - by $44.1 \%$, in outbred - by $58 \%$; while the average daily gain in sheep of the Bukovynian type of Askanian meat-wool breed was higher by $71.6 \%$, in outbred - by $5.5 \%$.

In the fourth experiment, at normal protein content in the diets of Bukovinian sheep of the Askanian meat-wool breed, nitrogen deposition in the body was $29.5 \%$ higher than in outbred ones; the average daily gains were correspondingly higher by $40.2 \%$. In the fifth and sixth experiments, when fed a low-protein diet, as expected, nitrogen deposition in sheep was low: in sheep of the Bukovinian type of Askanian meat-wool breed, it was $2.92 \mathrm{~g}$, in outbred $2.01 \mathrm{~g}$, ie was respectively 6.34 and $5.14 \mathrm{~g}$ lower than the animals in the third experiment; the average daily gains were smaller than in other experiments.

The results of the analysis of slaughter yield of meat (table 1) show that in sheep of the Bukovynian type of Askanian meat-wool breed in the first series of experiments it was higher by $32.5 \%$, in the second - by $17.7 \%$, in the third - by $\{8.8 \%$, in the fourth - by $17.8 \%$ than in outbred. outbred, with the same content of nitrogenous substances in the feed and their relatively greater intake with the feed of the Bukovinian type of Askanian meat-wool breed.

Type of Askanian meat-wool breed and outbred sheep correlates well with the activity of ammonia fixation processes - with increased or decreased synthesis of amino acids from $\alpha$ ketoglutaric acid and ammonium carbonate. (Lynchab et al., 2018).

\section{CONCLUSIONS AND RECOMMENDATIONS}

The greatest activity of biosynthesis of urea and glutamic acid was observed in experiments of the first and third series, when animals received rations with sufficient protein content.

a) The results of the analysis of slaughter yield of meat show that in sheep of the Bukovynian type of Askanian meat-wool breed in the first series of experiments it was higher by $32.5 \%$, in the second - by $17.7 \%$, in the third - by $20.8 \% . \%$, in the fourth by $17.8 \%$ than in outbred.

b) Increased muscle growth, high nitrogen deposition and a much lower percentage of urinary excretion of ammonia and urea nitrogen, as well as higher activity of enzymes of the ornithine cycle and glutamic acid synthesis in sheep of the Bukovinian type of 
INDEPENDENT JOURNAL OF MANAGEMENT \& PRODUCTION (IJM\&P)

http://www.ijmp.jor.br

v. 12, n. 6, Special Edition ISE, S\&P - November 2021

ISSN: 2236-269X

DOI: 10.14807/ijmp.v12i6.1751

Askanian meat-wool breed compared to outbred sheep to conclude that ammonia and urea in highly productive animals are less the end products of nitrogen metabolism than in low-yielding animals.

\section{REFERENCES}

Chernomyz, T. O., Lesyk, O. B., \& Pokhivka, M. V. (2014). The Bukovynian type of Askanian meat-wool sheep with crossbred wool is an important reserve for increasing the production of meat. Problems of zooengineering and veterinary medicine, 28 (1), 100-107. Retrieved from http://nbuv.gov.ua/UJRN/pzvm_2014_28\%281\%29 12.

Ibatullin, I. I., Zhukorsky, O. M., \& Bashchenko, M. I. (2017). Methodology and organization of scientific studies in creativity: a tool. Kyiv: Agrarian Science.Workshop On Feeding Farm Animals: Educ. Tool.

Kotsiumbas, H. I., Shcherbakovska, O. M., \& Kotsiumbas, I. Ia. (2012). Ekspertyza kovbasnykh vyrobiv histolohichnym metodom. Lviv. (in Ukranian)

Lynchab, S. A., O'Neill, A. M., Drummond, L., \& Álvareza, C. (2018). Opportunities and perspectives for utilisation of co-products in the meat industry. Meat Science, 144, 62-73. DOI: https://doi.org/10.1016/j.meatsci.2018.06.019.

Meat and Meat Products (National Standard of Ukraine) (2005). Method for the determination of total nitrite content (control method) (ISO 2918: 1975, IDT): DSTU ISO 2918: 2005. Effect from 2008-01-01. To: State Consumer Standard of Ukraine, 2010.

Nischemenko, M. P, Samoray, M. M., \& Prokopishina, T. B. (2012). The use of essential amino acids in the cultivation of various species of animals. Scientific and technical bulletin of IBT NAAS, 3-4, 437-443.

Pașca I., Cîmpean A., \& Pusta D. (2018). Carcass Characteristics of Purebred Tsurcana Lambs and F1 Crossbreds (Tsurcana $\times$ Vendeen). Bulletin of University of agricultural sciences and veterinary medicine, 75, 87-91. DOI: 10.15835/ buasvmcn-vm:005717.

Pokhyl, V. I., \& Mykolaychuk, L. P. (2019). Age-related variability of the woollen coat of Romanivska sheep breed. Theoretical and Applied Veterinary Medicine, 7(3), 172-176. doi: 10.32819/2019.71031.

Pokhyl, V. I., \& Mykolaychuk, L. P. (2019). Methods of improvement of the meat productivity of sheep. International Scientific Conference Scientific Development of New Eastern Europe: Conference Proceedings, Part II. Riga, Latvia: Baltija Publishing, 107110.

Polska, P. I. (2001). Askani meat-wool breed of sheep Encyclopedia of Modern Ukraine: electronic version [website] of the National Academy of Sciences of Ukraine, NTSh. Kiev. Institute of Encyclopedic Research of the National Academy of Sciences of Ukraine, Retrievied from https://esu.com.ua/search_articles.php?id=44442.

Prylipko, T., Koval, T., \& Kostash, V. (2020). Optimization of recipe turkey meat pate. Carpatian journal of food science and technology, 12(4), 98-112. DOI: https://doi.org/10.34302/crpjfst/2020.12.4.11.

Prylipko, T., Kostash, V., \& Koval, T. (2021). Modeling of microbiological and biochemical processes under the conditions of steam contact sterilization in containers of turkey meat 
INDEPENDENT JOURNAL OF MANAGEMENT \& PRODUCTION (IJM\&P)

http://www.ijmp.jor.br

v. 12, n. 6, Special Edition ISE, S\&P - November 2021

ISSN: $2236-269 X$

DOI: 10.14807/ijmp.v12i6.1751

pate. Independent Journal Of Management \& Production, 12(3), 318-334. DOI: http://dx.doi.org/10.14807/ijmp.v12i3.1444.

Scales, G. H., Bray, A. R., \& Baird, D. B. (2000). Effect of sire breed on growth, carcass, and wool characteristics of lambs born to Merino ewes in New Zealand. New Zealand J. of Agricultural Research, 43, 93-100. DOI: 10.1080/00288233.2000.951341213.

Vdovichenko, Y. V., Iovenko, V. M., \& Zharuk, P. G. (2016). The state and scientific support of the sheep industry in Ukraine. Scientific Bulletin "AskaniaNova", 9, 3-16.

Zonabend König, E., Ojango, J. M. K., \& Audho, J. (2017). Live weight, conformation, carcass traits and economic values of ram lambs of Red Maasai and Dorper sheep and their crosses. Tropical Animal Health and Production, 49, 121-129. DOI: 10.1007/s11250-0161168-5 14. 